23. SEALY, S. G. 1999. Further data on food items of Northern Saw-whet Owls (Aegolius acadicus brooksi) on the Queen Charlotte Islands, British Columbia. Western Birds 30:200-205.
25. SWENGEL, S. R., and A. B. SWENGEL. 1992. Diet of Northern Saw-whet Owls in southern Wisconsin. Condor 94:707-711.

24. SMITH, H. C. 1976. Comparison of food items found in pellets of seven species of owls. Edmonton Naturalist 4(2):36-38.

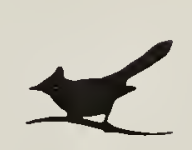

\title{
HABITAT FEATURES IMPORTANT TO BURROWING OWL BREEDING SUCCESS IN SASKATCHEWAN
}

\begin{abstract}
ROBERT G. WARNOCK and MARGARET A. SKEEL, Nature Saskatchewan, 206-1860 Lorne Street, Regina, SK S4P 2L7; warnockr@accesscomm.ca OR mskeel@naturesask.com
\end{abstract}

Burrowing Owls are unique among owls in that they nest in mammal burrows (usually ground squirrel or badger burrows in western Canada). They nest as solitary pairs or small loose colonies in open pastures with short grass, and also use taller grass-forb areas for hunting. 2, 8, 9, 22 The Burrowing Owl has been classified as an endangered species in Canada since 1995. ${ }^{24}$ The Saskatchewan owl population declined about 95 percent between 1987 and 2001, and the species range has been shrinking southward and westward since the 1940s (Nature Saskatchewan unpublished data). ${ }^{10,19}$ Habitat loss and fragmentation have been identified as the ultimate factors in the decline of the owl population in Saskatchewan.2, 21, 24 In 2000 , only 20 percent of former grasslands in Saskatchewan remained as natural habitat, and in highly arable areas it was as low as two percent. ${ }^{7}$ The Operation Burrowing Owl (OBO) program, delivered by Nature Saskatchewan, was launched in 1987 to protect grassland habitat for Burrowing Owls through voluntary landowner stewardship. ${ }^{19}$
Intensive studies of the Burrowing Owl in Saskatchewan since 1982 have looked at breeding biology and productivity, diet and foraging strategies, population dynamics, dispersal, migration mortality and postfledgling ecology. 2, 13, 18, 20, 21, 23 The only study of the relationships of habitat patterns and owl population dynamics across the owl's range in Saskatchewan examined population turnover but not breeding success. ${ }^{21}$ In 2000, the authors undertook a pilot study of habitat features that might be important to owl breeding success; this was conducted in conjunction with a program to visit all $\mathrm{OBO}$ members with nesting owls. The goal of the study was to determine whether habitat features play an important role in breeding success, and to identify those that would merit further study.

\section{Methods}

The study area included all known active OBO and Grasslands National Park (GNP) nest sites across the Burrowing Owl's current range in southern Saskatchewan (Figure 1). By early July, landowners, public land 
managers and Burrowing Owl researchers had reported locations and numbers of nesting Burrowing Owls and their young to OBO. Each reported owl nest site, as well as known active nest sites in GNP, was visited at least once between July 14 and August 25 to determine breeding success or failure, and to measure habitat characteristics. A total of 92 nest sites were visited.

A successful owl nest was defined as having at least one fledgling surviving to 42 days of age. ${ }^{4}$ Most fledglings appear above ground around the end of June and stay close to the nest burrow for several weeks. Owl fledglings were identified in the field by their unmarked buffy or yellowish beige bellies; in contrast, adult owls have numerous darker brown spots on the belly. A failed nest was defined as one that was destroyed or abandoned, or one with no fledglings seen by landowners or biologists after June 30. It was logistically impossible to regularly check all nests and use the Mayfield method to estimate overall breeding success. ${ }^{14}$ Therefore, we used the apparent estimator ([number of successful nests/ total nests observed]*100) of nesting success, recognizing this estimator may be inflated due to lower likelihood of finding failed nests. ${ }^{15}$
Twenty-one habitat characteristics selected for likely biological importance, potential statistical significance, and ease of measurement, were measured at each nest site. Habitat parameters recorded at each site included surrounding land use $(200 \mathrm{~m}$ and $2 \mathrm{~km}$ radii); distances to nearest road, closest owl pair, and farmyard; presence of one or more wetlands within $2 \mathrm{~km}$; nest type (natural or nest box); presence or absence of grazing; soil type (from soil maps), and habitat type (pasture, grass patches in cropland or roadside). Also noted by abundance category (for simplification and time savings in the field) were badger holes, ground squirrel hole clusters, owl perches, utility poles, nearby farms and single trees. Badger holes were distinguished from Richardson's ground squirrel holes by larger size $(30 \mathrm{~cm}$ in diameter as compared to the $7-8 \mathrm{~cm}$ diameter for ground squirrels) and larger mounds of soil at the entrance. All examined badger holes appeared to be inactive. A ground squirrel hole cluster represented a tunnel system for a single adult ground squirrel. A hole cluster usually contained five to fifteen holes. A minimum gap of $10 \mathrm{~m}$ between hole clusters was used to delineate separate hole clusters.

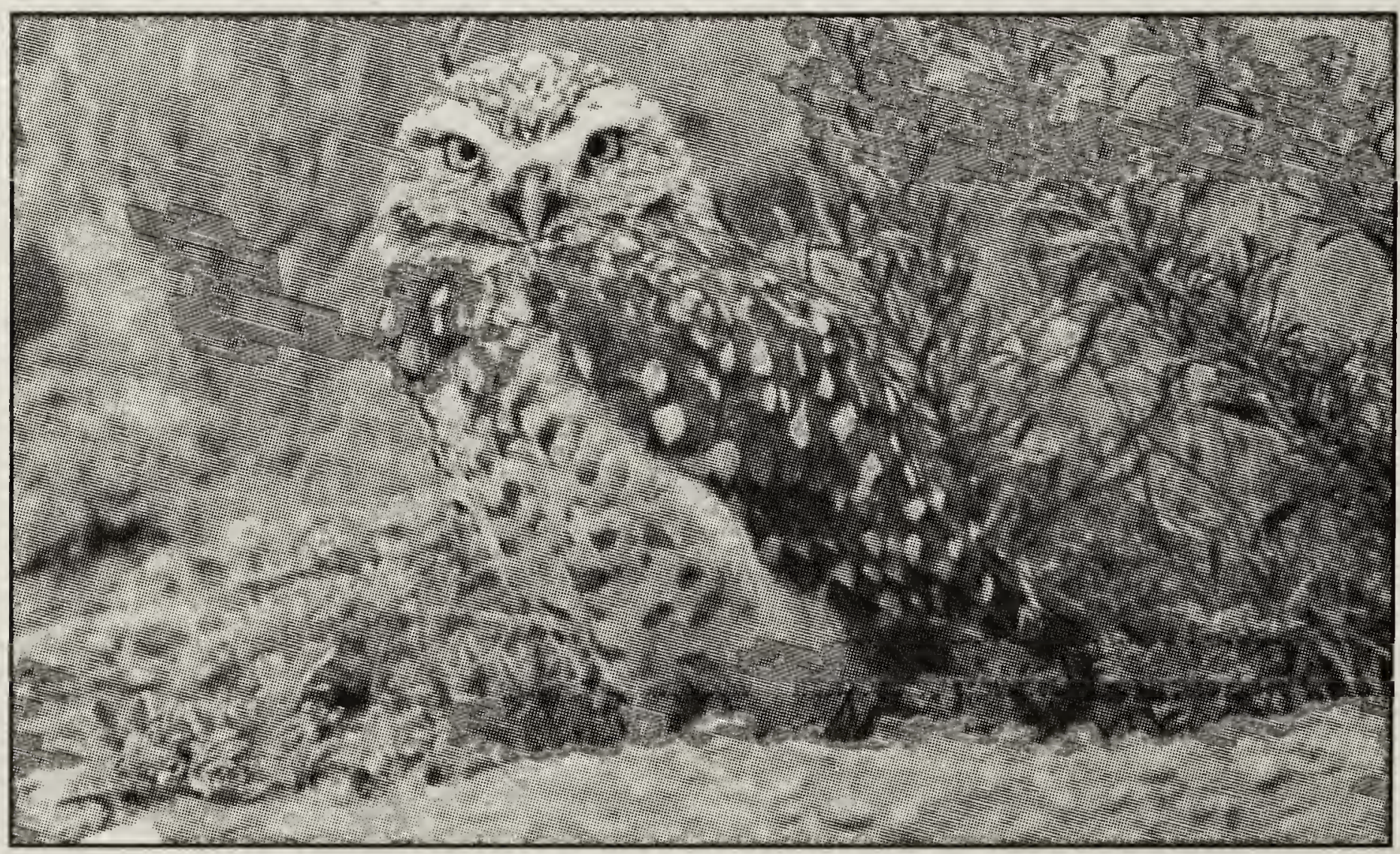




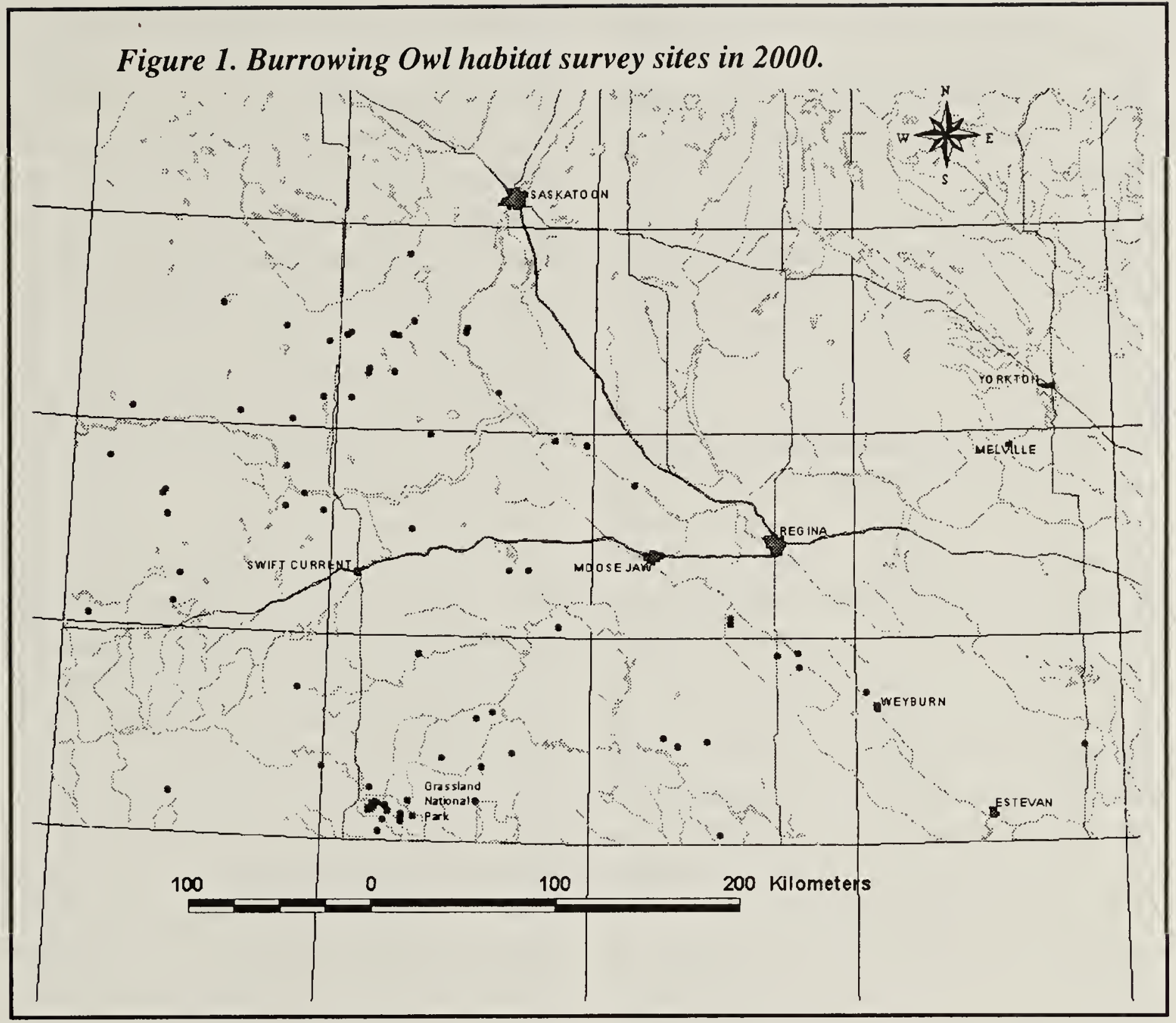

Since the majority of reported owl foraging movements are within $200 \mathrm{~m}$ and $2 \mathrm{~km}$ radii of nests during the day and at night, respectively, in Saskatchewan, we used these two radii to calculate percentages of land use types around owl nests. ${ }^{9}$ All characteristics, except for the land use parameters within a $2 \mathrm{~km}$ radius of owl nest sites, were measured in the field during a site visit. Land use within a $2 \mathrm{~km}$ radius of each owl nest was calculated using the Saskatchewan Digital Land Cover map that was created from LANDSAT satellite imagery taken in 1992 and 1993. Areas within a $2 \mathrm{~km}$ radius of Burrowing Owl nest sites were selected in ArcView 3.2 and cover types by area were determined using Spatial Analyst (an ArcView GIS extension) and then converted to percentages. ${ }^{5}$ To reduce the number of variables in the analysis, we combined the 24 standard satellite imagery cover classes on the map into four broad cover types: grassland, farmland, wetland and forest. Where there were discrepancies between the map and ground-truthing in the immediate vicinity of the nest. (as was true for $20 \%$ of sites in the agricultural landscape), areas and percentages were adjusted.

Non-parametric statistics were used as the data lacked normality after transformation attempts, had non-linearity and had unequal variances. ${ }^{25}$ Multivariate analysis was thus precluded. In addition, relatively small sample sizes $(<100)$, and limitations in precision of measurements and use of some categorical variables, also contributed to the decision not to use multivariate statistics. Mann-Whitney U-tests and Chi-square $\left(\Pi^{2}\right)$ tests were used to compare successful nests to failed nests, as well as to compare habitat characteristics at owl sites in the agricultural landscape with characteristics in GNP. ${ }^{25} \mathrm{We}$ used a statistical significance level of $\mathrm{P} \leq 0.05$ unless otherwise indicated. 
Owl nesting data from the same locations in GNP in 1998 (17 nests) and 1999 (28 nests) were added to our 2000 data to increase sample sizes of successful and failed nests (Geoff Holroyd, unpublished data). All owl nest sites in GNP occurred in Black-tailed Prairie Dog colonies, and there were no changes in the habitat of these colonies between years (Geoff Holroyd, pers. comm.).

\section{Results}

Of the total of 92 Burrowing Owl nest sites examined in 2000, 67 were in the agricultural landscape (65 on privately owned land and two in Prairie Farm Rehabilitation Administration pastures), and 25 nest sites were in Grasslands National Park (GNP). A total of 111 adults and 133 fledglings were counted during site visits. In the agricultural landscape, 62 solitary pairs and one loose colony of nesting owls were recorded (five pairs in one privately owned quarter-section south of Regina). In contrast, GNP in 2000 had a higher proportion of colonies; five different quarter sections in GNP had two to four pairs each, totalling 13 pairs, in addition to the 12 solitary pairs in other quarter sections.

\section{Breeding Success}

Owl breeding success did not differ ( $P>0.05$ ) between the agricultural landscape and GNP, and was $68 \%$ overall (agricultural landscape, $66 \%$ or 44 of 67 sites; GNP, $76 \%$ or 19 of 25 sites). Breeding failure was attributed to predation ( 7 sites), flooding due to record rainfall (2 sites near Vanguard), land breakage (1 site), cattle trampling (1 site), burrow collapse (1 site), severe weather in GNP (6 sites) and unknown factors (11 sites). ${ }^{11}$

\section{Agricultural Landscape vs. Grasslands National Park}

Burrowing Owl nest sites in the predominantly agricultural landscape outside GNP differed significantly from sites in Grasslands National Park (GNP) in which all were in prairie dog colonies. Appendix 1 lists the habitat characteristics that differ significantly between nest sites on agricultural land vs. GNP. Nest sites in the agricultural landscape were surrounded by more farmland (at $200 \mathrm{~m}$ and $2 \mathrm{~km}$ radii), less grassland (at $200 \mathrm{~m}$ and $2 \mathrm{~km}$ radii) and less wetland (at $2 \mathrm{~km}$ radius) than nest sites in GNP. Owl sites in the agricultural landscape had more fence line length, roads, single trees, utility poles, owl perch sites, occupied farms, badger holes, and ground squirrel hole clusters surrounding them than owl sites in prairie dog colonies in GNP. In addition, owl nests in the agricultural landscape were also closer to roads and farms, and had fewer abandoned nearby farms. Because of the differences in the landscapes, we looked at the agricultural landscape separately from GNP when we analyzed these habitat characteristics at successful vs. failed owl sites.

\section{Successful Nests vs. Failed Owl Nests in the Agricultural Landscape}

In the agricultural landscape, four habitat characteristics showed a significant difference between successful and failed owl nests (See Table 1). Compared to failed nests, successful nests had more Richardson's ground squirrel hole clusters and more badger holes within $100 \mathrm{~m}$ of the nest. Also, successful nests had fewer single trees within sight and a higher percentage of wetland within $2 \mathrm{~km}$ of the nest, than did failed nests. Owl sites with nearby wetland areas (46 sites) had a nesting success of $76 \%$ vs. $43 \%$ for sites with no nearby wetland (21 sites). There were no statistically significant relationships between breeding success and the following habitat characteristics: distance to next nearest owl pair, distance to nearest road, and number of potential owl perches.

\section{Successful Nests vs. Failed Owl Nests in Grasslands National Park}

Two habitat characteristics differed significantly between successful and failed owl nests in GNP during 1998-2000. Successful nests were closer to farmyards $(\mathrm{P}<0.05)$, and also closer to roads $(\mathrm{P}<0.10)$, than failed nests (Table 1). 
Nests in GNP were mostly located near riparian habitat along valley bottoms in 1998 to 2000 . In 2000 , there was a negative relationship between breeding success and wetland area within $2 \mathrm{~km}$ of nests: wetlands comprised an average of $18 \%$ of the area around 19 successful nests compared to an average of $30 \%$ around 6 failed nests. Breeding success was $78 \%$ (23 sites) for sites with one or more wetland areas within $2 \mathrm{~km}$ and $50 \%$ for sites ( 2 sites) with no wetland areas within $2 \mathrm{~km}$ of nests.

\section{Other Habitat Features}

Owl breeding success differed significantly $(\mathrm{P}<0.05)$ in terms of grassland land use practice, and was $50 \%$ at sites with no grazing or mowing ( 8 sites), $25 \%$ at sites that were mowed (4 sites) and $73 \%$ at sites with grazing ( 80 sites). Nesting success did not differ significantly between natural nests $(67 \%, 82$ sites) and artificial nest boxes ( $80 \%, 10$ sites). It also did not differ significantly among broad soil groups, and was $59.2 \%$ in lacustrine soils (27 sites), $78.6 \%$ in alluvial soils (28 sites), $73.1 \%$ in morainal soils ( 26 sites) and $54.6 \%$ in other soils (11 sites). In a comparison of habitats, breeding success was $71 \%$ in pasture ( 86 sites), $50 \%$ in small grass patches $(<0.1 \mathrm{ha})$ in cultivated fields ( 2 sites), and $25 \%$ in roadsides (4 sites).

\section{Discussion}

\section{Breeding Success in the Agricultural}

Landscape

In the agricultural landscape, more nearby Richardson's ground squirrel hole clusters and more badger holes, fewer nearby single trees, presence of nearby wetlands and amount of wetland area within $2 \mathrm{~km}$ were shown to be important to owl breeding success.

Ground squirrel and badger holes are important in providing a selection of nest and roost sites, as escape terrain and for juvenile dispersal. ${ }^{18}$ Other studies have shown that adequate burrow availability is a basic habitat requirement for Burrowing
Owls. ${ }^{3.8}$ For example, occupied owl sites were found to have a greater density of ground squirrel holes than unoccupied nest sites on the Regina Plain in Saskatchewan. ${ }^{12}$

Trees are used as nest sites and perches by larger raptors, and raptors are significant predators on juvenile owls. ${ }^{20}$ Other studies have shown that a lack of trees is another basic habitat requirement for Burrowing Owls. ${ }^{8}$ Over time, lower owl densities and nest persistence were found in areas with more trees near Hanna, Alberta. ${ }^{2}$

The proximity and amount of wetland habitat are important as a source of additional prey for Burrowing Owls because these habitats support enhanced insect and small mammal populations; owls are known to glean insects from the taller vegetation. ${ }^{9}$ Increased food availability can boost fledgling success in Burrowing Owls. ${ }^{23}$ Rodents and shrews may benefit from the additional food and cover provided by taller vegetation, and become vulnerable to predation by owls while traversing in open areas or along habitat edges., ${ }^{2} 16$ However, it is important to note that wetland areas in this study were determined from satellite imagery taken in 1993, and these areas may have varying levels of water in different years. In addition, the positive correlation between owl breeding success and wetlands needs further investigation because our study grouped together diverse types of wetlands that differ in hydroperiod, hydrology and faunal and floral communities.

The lack of a relationship between breeding success and distance to next nearest owl pair, distance to nearest road, and numbers of potential owl perches in the agricultural landscape differs from studies in Oregon and Colorado.6, 17

\section{Breeding Success in GNP}

In contrast to the agricultural landscape, in GNP there was no apparent relationship between owl breeding success and numbers of nearby burrows and trees. Owls nested 
within prairie dog colonies where there was no shortage of available holes. There were fewer trees in GNP than in the agricultural landscape, which may account for the lack of a difference in the number of single trees between successful and failed nests.

A negative relationship between wetland area and owl breeding success in GNP in 2000 was likely due to flooding caused by a severe thunderstorm (with record rainfall north of GNP) in July 2000 at a small sample size of failed nests. ${ }^{11}$ With the addition of 1998 and 1999 owl data, this negative relationship disappeared. However, risk to young owls of predation may be lower in grassland areas than in riparian or wetland areas. ${ }^{16}$ Although sample size is small, higher breeding success with presence of nearby wetland areas in GNP is consistent with the importance of nearby wetland areas to breeding success in the agricultural landscape. The presence of wetland areas in GNP is likely important.

Factors that increased breeding success in GNP in 1998-2000 were proximity to farmyards and roads. This may be due to reduced distances to potential feeding areas. Burrowing Owls are known to use roadside areas as feeding areas, and these foraging areas were within the owl's maximum foraging distance of $10 \mathrm{~km}$ (Robert Sissons, unpublished data). ${ }^{9}$ In Colorado, a positive relationship between proximity to roads and burrow occupancy by Burrowing Owls in prairie dog colonies was found in 1990 but not in $1991.1^{17}$ The foraging advantages along roads and in farmyards may outweigh the risks of collision with vehicles and predation by domestic pets. As in the agricultural landscape, in GNP we found no relationship between breeding success and distance to next nearest owl pair, and number of potential owl perches.

A lack of relationship between breeding success and other habitat characteristics in GNP may be due to the uniformity of prairie dog colonies and spatial autocorrelation.
Spatial autocorrelation is the correlation of variables in reference to spatial location of the variables. Spatial autocorrelation of variables likely occurred in GNP as five different quarter sections had 13 of 25 recorded owl pairs ( 2 to 4 pairs per quartersection, 10 successful nests, 3 failed nests) in 2000. However, prairie dog colonies provide good habitat and are known to be important for Burrowing Owls: studies in the United States have shown that declines of these owls are correlated with declines in prairie dog colony size, and smaller and isolated prairie dog colonies suffer from higher nest predation..$^{1,4}$ In contrast, spatial autocorrelation in the agricultural landscape was minimal as occurrence of more than 1 pair of owls in the same quarter section was rare (1 of 63 quarter-section cases).

\section{Other habitat features}

Breeding success was significantly lower at sites without grazing (sites with no grazing or mowing, and mowed sites) than sites with grazing in the agricultural landscape. Although mowed areas may resemble naturally grazed areas in having shorter vegetation, disturbance from people and mowing machines could lower owl breeding success; further research on mowing effects is needed. These results generally support previous studies in illustrating the importance of grazing and keeping vegetation short around nest and roost burrows., ${ }^{2}$ In GNP, all owl nest sites were in heavily grazed prairie dog colonies and there were no visible differences in grazing between successful and failed owl nests.

Our sample size of artificial nest boxes may be too small to allow detection of a difference in breeding success between these sites and natural burrows. However, breeding success measured by nest survival and number of young produced was higher in artificial nest boxes than natural nests in the Regina Plain in recent years. ${ }^{23}$

\section{Limitations}

We recognize the following limitations to 
our study: small $(<100)$ sample sizes, most data was from one breeding season, inability to monitor nests at least once a week for a more precise assessment of breeding success in order to use of the Mayfield estimator of daily survival, use of simplified habitat features (e.g. wetland types) and categorical variables (e.g. number of badger holes) in analyses, and data that did not allow us to use multivariate statistics. Multivariate statistics can be used to reduce spurious statistically significant univariate relationships, to examine interacting variables together, and to examine spatial autocorrelation in variables between nest sites. Although there were these limitations, the results of our study indicate there is a relationship between some habitat features and Burrowing Owl breeding success in Saskatchewan that merits further investigation.

\section{Conclusions}

Habitat considerations useful in management of areas with Burrowing Owl nests in the agricultural landscape include the importance of badger and ground squirrel populations, the negative effect of presence of trees on owl breeding success, the positive effect of presence of wetland areas, and grazing near nest sites. In GNP, abundant holes, lack of trees, sufficient wetland areas and grazing levels are likely more consistent at potential nest sites across the landscape and, if maintained, (e.g. maintaining prairie dog colonies), are of less management concern. By including the effect of these habitat features when taking management actions, we may increase Burrowing Owl breeding success.

\section{Acknowledgements}

We thank the following people for their help with this study: private landowners participating in Operation Burrowing Owl, staff at Eagle Lake PFRA pasture, Danielle Todd and Ray Poulin (University of Regina), Geoff Holroyd (Canadian Wildlife Service), Sue Michalsky (Nature Conservancy of Canada), and Laura James (Parks Canada) for providing habitat and breeding success data at various locations; Dale Hjertaas and Don McKinnon (Saskatchewan Environment) for help with study design and analysis; Jeff Keith and Steve Porter (Saskatchewan Conservation Data Centre) for calculating land use from satellite imagery and for creating Figure 1; Rob Sissons (University of Alberta/Parks Canada) and G. Holroyd for providing unpublished data, and Patrick Moore (Nature Saskatchewan) for his valuable assistance with fieldwork. We thank G. Holroyd, R. Poulin, and two anonymous reviewers for comments on drafts of the manuscript. We also wish to thank Lynda Langford and the staff at Policy and Legislation Branch, Saskatchewan Environment, for their support during the writing of this article. Funding for this project was provided by Nature Saskatchewan, Canadian Council for Human Resources in the Environment Industry - Environmental Youth Corps, Saskatchewan Environment Fish and Wildlife Development Fund, Government of Canada - Habitat Stewardship Program for Species at Risk, World Wildlife Fund and Canadian Wildlife Service - Endangered Species Recovery Fund, Environment Canada - EcoAction 2000, and Elsa Wild Animal Appeal of Canada. Nature Saskatchewan receives funding from Saskatchewan Lotteries.

1. BAKER, B.W., T.R. STANLEY, and G.E. PLUMB. 2000. Nest predation on blacktailed prairie dog colonies. Journal of Wildlife Management 64: 776-784.

2. CLAYTON, K.M. and J.K. SCHMUTZ. 1999. Is the decline of Burrowing Owls Speotyto cunicularia in prairie Canada linked to changes in Great Plains ecosystems? Bird Conservation International 9: 163-185.

3. DESMOND, M.J. and J.A. SAVIDGE. 1996. Factors influencing Burrowing Owl (Speotyto cunicularia) nest densities in western Nebraska. American Midland Naturalist 136: 143-148.

4. DESMOND, M.J, J.A. SAVIDGE and K.M. ESKRIDGE. 2000. Correlations between Burrowing Owl and Black-tailed Prairie Dog 


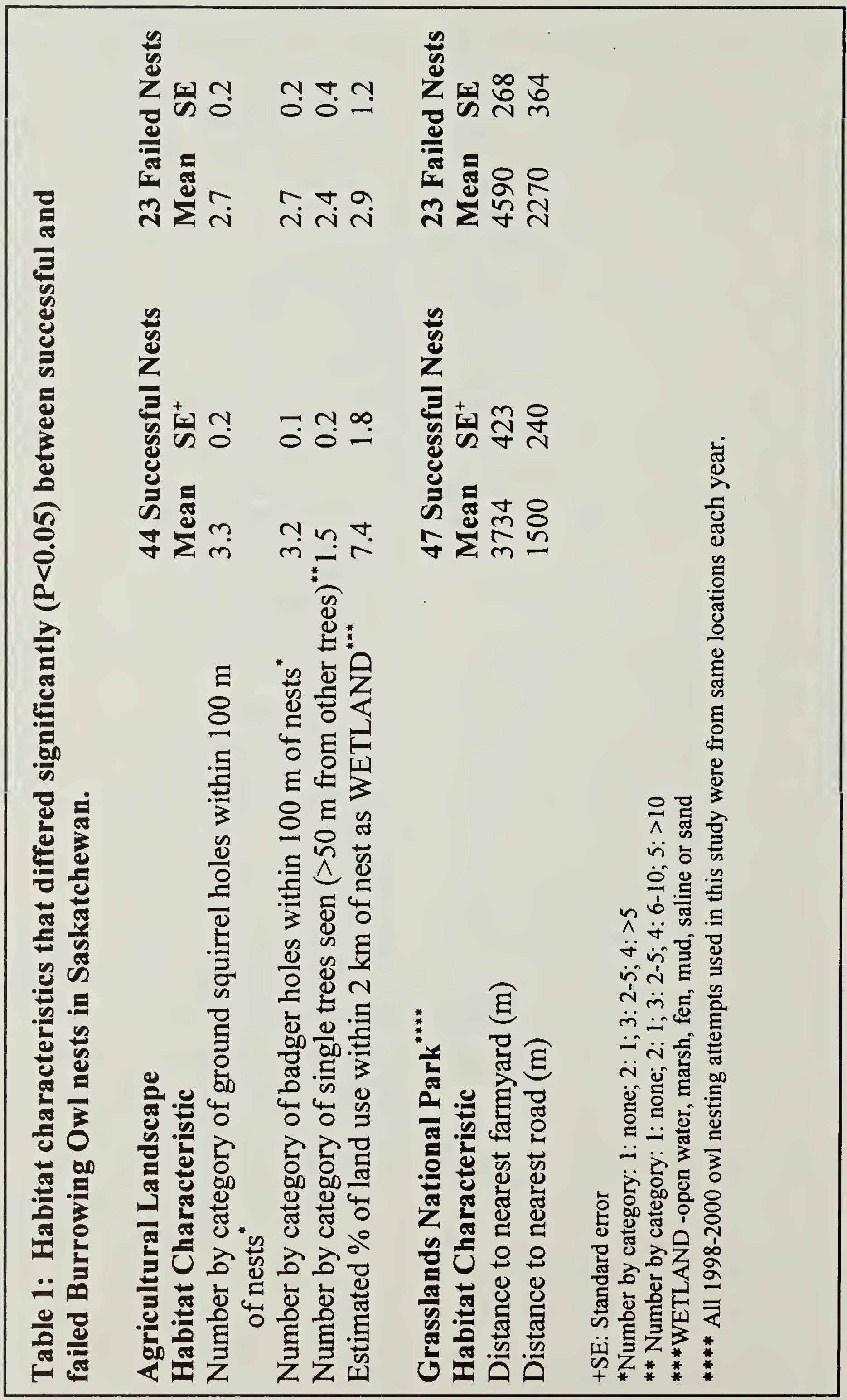




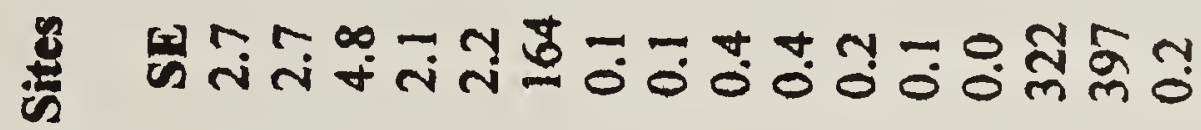
辞

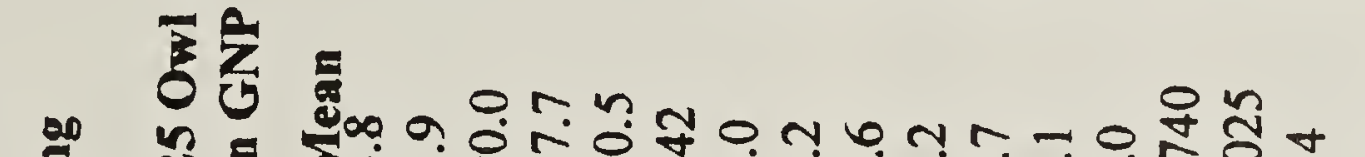

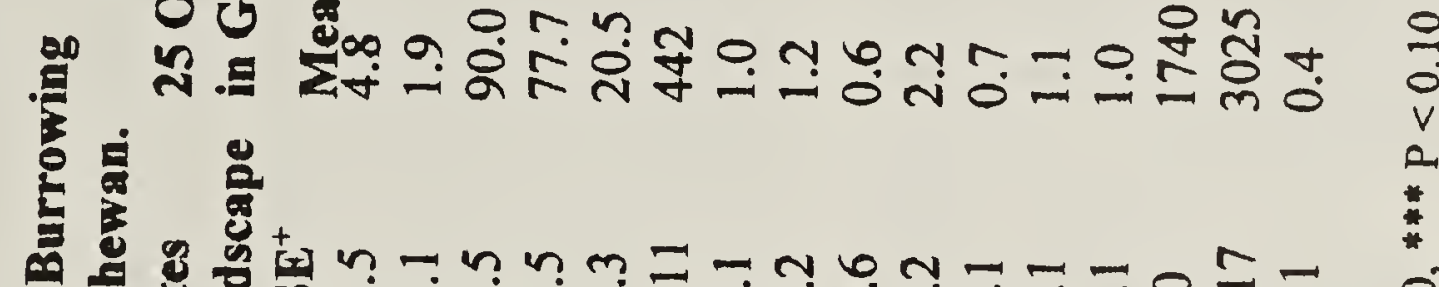

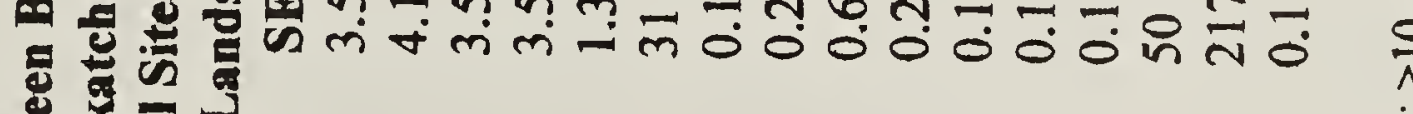

密

宩.

.



둘

可

는

용

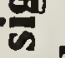

은

t)

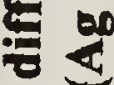

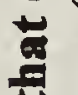

F

3

든

.

$\Phi$

己

농

0

홍

능

동

$\ddot{-}$

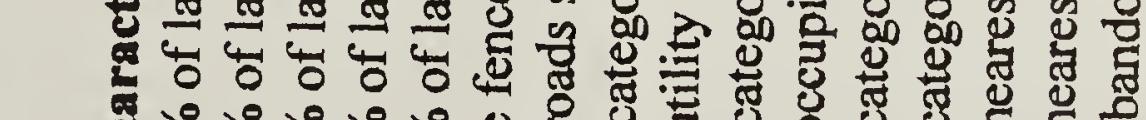

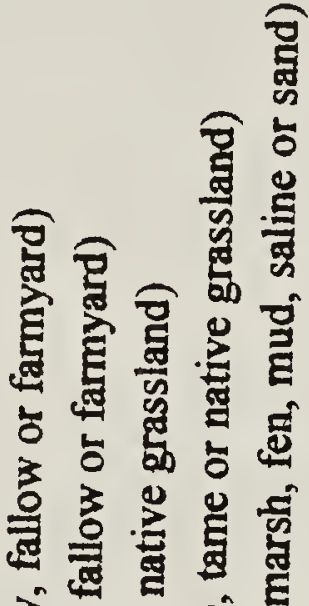

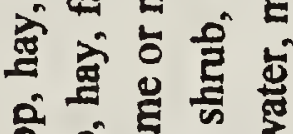

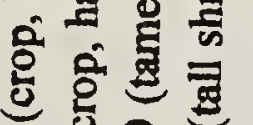

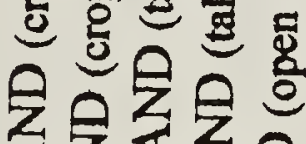

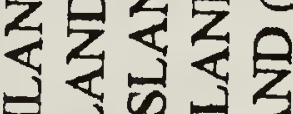

定零出

$2 \sum_{2} \leq \mathbb{1}$

I $\frac{1}{2} \frac{1}{3}$

ปู

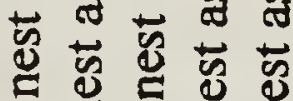

o

E $\mathrm{E}$ ह

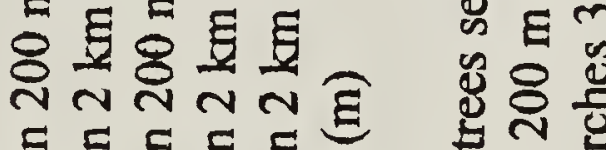

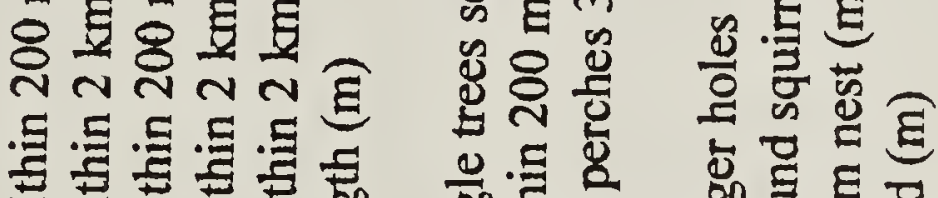

n

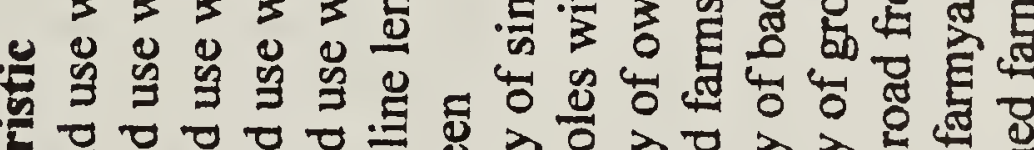

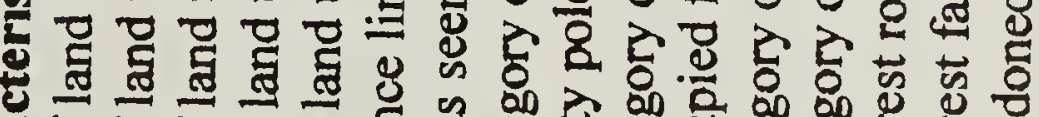

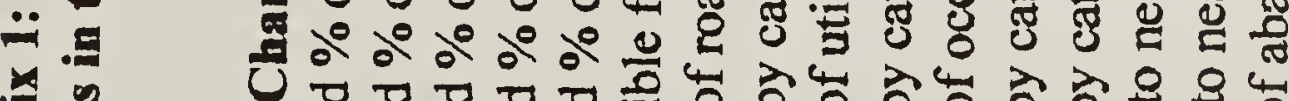

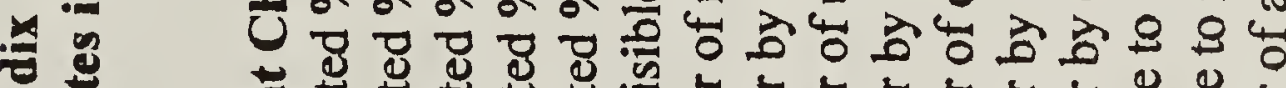

घ.

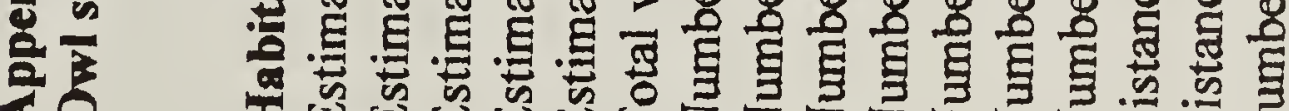

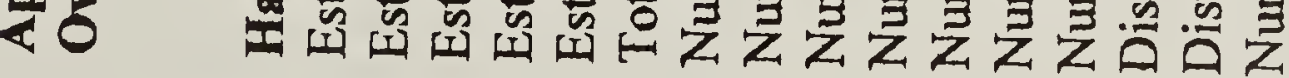


declines: A 7-year analysis. Journal of Wildlife Management 64: 1067-1075.

\section{ENVIRONMENTAL SYSTEMS} RESEARCH INSTITUTE (ESRI). 1999. ArcView 3.1 and Spatial Analyst Extension. ESRI Ltd. Redlands, California.

6. GREEN, G.A. and R.G. ANTHONY. 1989. Nesting success and habitat relationships of Burrowing Owls in the Columbia Basin, Oregon. Condor 91: 347-354

7. HAMMERMEISTER, A.M., D. GAUTHIER and K. McGOVERN. 2001. Saskatchewan's Native Prairie: Statistics of a Vanishing Ecosystem and Dwindling Resource. Native Plant Society of Saskatchewan Inc., Saskatoon, Saskatchewan.

8. HAUG, E.A., B.A. MILLSAP and M.S. MARTELL. 1993. Burrowing Owl (Speotyto cunicularia). In: The Birds of North America No. 61. A. Poole and F. Gill (eds.). The Academy of Natural Sciences, Philadelphia, Pennsylvania; The American Ornithologists Union, Washington, D.C.

9. HAUG, E.A. and L.W. OLIPHANT. 1990. Movements, activity patterns and habitat use of Burrowing Owls in Saskatchewan. Journal of Wildlife Management 54: 27-35.

10. HOUSTON, C.S., D.J. HJERTAAS, R.L. SCOTT and P.C. JAMES. 1996. Experience with Burrowing Owl nest-boxes in Saskatchewan with comment on decreasing range. Blue Jay 54: 136-140.

11. HUNTER, F.G., D.B. DONALD, B.N. JOHNSON, W.D. HYDE, J.M. HANESIAK, M.O.B. KELLERHALS, R.F. HOPKINSON and B.W. OEGEMA. 2002. The Vanguard torrential storm (meteorology and hydrology). Canadian Water Resources Journal 27: 213-227.

12. JAMES, P.C., T.J. ETHIER, G.A. FOX and M. TODD. 1991. New aspects of Burrowing Owl biology. In: Holroyd, G.L., G. Burns and H.C. Smith (eds.). Proceedings of the Second Endangered Species and Prairie Conservation Workshop, Regina Saskatchewan, January 1989. Natural History Occasional Paper No.15, Provincial Museum of Alberta, Edmonton, Alberta. p. 226-227.
13. JAMES, P.C., T.J. ETHIER and M.K. TOUTLOFF. 1997. Parameters of a declining Burrowing Owl population in Saskatchewan. Raptor Research Report 9: 34-37.

14. JOHNSON, D.H. 1979. Estimating nest success: The Mayfield method and an alternative. Auk 96: 651-661.

15. JOHNSON, D.H. and T.L. SHAFFER. 1990. Estimating nest success: When Mayfield wins. Auk 107: 595-600.

16. LARIVIÈRE, S. and F. MESSIER. 2000. Habitat selection and use of edges by striped skunks in the Canadian prairies. Canadian Journal of Zoology 78: 366-372.

17. PLUMPTON, D.L. and R.C. LUTZ. 1993. Nesting habitat use by Burrowing Owls in Colorado. Journal of Raptor Research 27: 175-179.

18. SCHMUTZ, J.K. 1997. Selected microhabitat variables near nests of Burrowing Owls compared to unoccupied sites in Alberta. Raptor Research Report 9: 80-83.

19. SKEEL, M.A., J. KEITH and C.S. PALASCHUK. 2001. A population decline of Burrowing Owls in Saskatchewan documented by Operation Burrowing Owl. Journal of Raptor Research 35: 371-377.

20. TODD, L.D. 2001. Dispersal patterns and post-fledgling mortality of juvenile Burrowing Owls in Saskatchewan. Journal of Raptor Research 35: 282-287.

21. WARNOCK, R. 1997. Is habitat fragmentation a factor in the decline of the Burrowing Owl in Saskatchewan? Blue Jay 55: 222-228.

22. WEDGEWOOD, J.A. 1976. Burrowing Owls in south-central Saskatchewan. Blue Jay 34: $26-44$.

23. WELLICOME, T.I., G.L. HOLROYD, K. SCALISE and E.R. WILTSE. 1997. The effects of predator exclusion and food supplementation on Burrowing Owl (Speotyto cunicularia) population change in Saskatchewan. In: J.R. Duncan, D.H. Johnson and T.H. Nicholls (eds.), Biology and Conservation of Owls of the Northern 
Hemisphere, Second International Symposium Winnipeg, Manitoba, February 1997. General Technical Report NC-190. United States Department of Agriculture, Forest Service, North Central Forest Experiment Station, St. Paul, Minnesota, pp. 487-497.

24. WELLICOME, T.I. and E.A. HAUG.
1995. Updated Report on the Status of the Burrowing Owl in Canada. Committee on the Status of Endangered Wildlife in Canada, Ottawa, Ontario.

25. ZAR, J.H. 1996. Biostatistical Analysis. $3^{\text {rd }}$ Edition. Prentice-Hall, Inc., Upper Saddle River, New Jersey.

\section{ADDITIONAL NOTES ON THE DOVEKIE SPECIMEN FROM MANITOBA}

SPENCER G. SEALY, Department of Zoology, University of Manitoba, Winnipeg, MB R3T 2N2, and HARRY R. CARTER, Department of Wildlife, Humboldt State University, Arcata, CA 95521, U.S.A.

\section{Introduction}

The Dovekie (Alle alle), or Little Auk, is a high-arctic species that breeds in large numbers on Greenland, Svalbard (Spitzbergen), Franz Josef Land and Novaya Zemlya, with small numbers nesting on Iceland and Baffin Island. ${ }^{20}$ Some nesting colonies, particularly in northwestern Greenland, are comprised of millions of individuals. ${ }^{20}$ Small numbers of Dovekies also occur in the Bering Sea and adjacent waters and breeding is suspected at several sites. ${ }^{5}$ Although nothing is known of the seasonal movements of Dovekies in the Bering Sea, in the Atlantic Ocean, Dovekies winter offshore in low-arctic waters from Newfoundland to northern Norway and occur regularly off Nova Scotia and in the Gulf of Maine, northern Scotland and the North Sea. ${ }^{20}$, ${ }^{31}$ From time to time, driven by food shortages caused in some years by severe storms, thousands of Dovekies move south of the normal winter range, in the western Atlantic Ocean, as far as Cuba and Madeira. ${ }^{13}$ During some of these movements many individuals are blown on to shore, resulting in "wrecks" of dead and weakened birds inland and along the Atlantic coast of North America.7, 10, 18, 27. 28, 29, 34

Seventeen Dovekies are known to have reached inland as far as the Great Lakes and surrounding region of North America. 6, 12, 23, ${ }^{24}$ One of these was collected north and west of the Great Lakes, along the eastern shore of Lake Winnipeg, in central Manitoba. ${ }^{1,11,16,22}$ Additional details pertaining to this specimen are presented in this paper and the circumstances surrounding the occurrence of a Dovekie in Manitoba are examined.

\section{The Dovekie}

A Dovekie swimming weakly near the shore of Lake Winnipeg at Warren Landing $\left(53^{\circ} 41^{\prime} \mathrm{N}, 97^{\circ} 52^{\prime} \mathrm{W}\right), 37 \mathrm{~km}$ southwest of Norway House, was collected by Constable James MacDonald on 7 November 1944. The specimen was sent to Gerald W. Malahar, acting supervisor of the Manitoba Department of Natural Resources, who forwarded it to Lawrence T.S. Norris-Elye, curator at the former Manitoba Provincial Museum. ${ }^{16,22}$ The dried, unsexed specimen 